\title{
Kaitan Pembelajaran Bahasa Indonesia dengan Lingkungan Hidup
}

\author{
Elsa Dewi Saputri (19016089) \\ elsadewisaputri18@gmail.com
}

Lingkungan hidup adalah segala sesuatu yang berada di sekeliling manusia sebagai pribadi atau di dalam proses pergaulan hidup dan hubungan antara berbagai organisme tempat tinggalnya. Seorang intelektual terkhusus siswa, inilah yang menjadi kebutuhan primernya yang terjadi secara sadar atau kurang sadar dalam menjalani kehidupannya. Antara manusia dan lingkungan hidupnya terdapat hubungan yang timbal balik. Manusia mempengaruhi lingkungan hidupnya, dan sebaliknya manusia dipengaruhi oleh lingkungan hidupnya dan tidak terpisahkan satu sama lain (Guci et al, 2018). Guci et at (2018) juga menambahkan bahwa lingkungan hidup sangat diperlukan bagi peserta didik, masyarakat, bangsa dan negara. Sebab, saat ini pembangunan yang banyak dilaksanakan secara besarbesaran di Indonesia dapat membawa dampak negatif terhadap lingkungan hidup, pencemaran sungai-sungai, pencemaran asap beracun pada kendaraan bermotor dan masih banyak lagi. Oleh sebab itu, seorang siswa didorong kecerdasan dan keintelektualnya untuk menulis karangan argumentasi tentang lingkungan hidup, sehingga mampu mempengaruhi pembaca agar menjaga lingkungan hidup demi kelangsungan hidup manusia.

Salah satu upaya penyelesaian masalah lingkungan yang berkelanjutan ini adalah dengan menanamkan sejak dini kepada generasi muda tentang pentingnya menjaga lingkungan. Hal-hal kecil seperti tidak membuang sampah sembarangan, menggunakan air seperlunya, dan lain sebagainya merupakan langkah awal yang bisa dilakukan. Menanamkan rasa tanggung jawab dan kesadaran akan menjaga lingkungan dapat dilakukan di sekolah dengan menerapkan materi lingkungan dalam pembelajaran. Salah satu pembelajaran yang dapat dikaitkan dengan materi lingkungan adalah pembelajaran bahasa. Menurut Uyar dan Ensar (dalam Ramadhan et al, 2019), menggunakan tema lingkungan dalam pembelajaran teks dapat memicu minat siswa dalam mempelajari bahasa dan secara berimplikasi dapat meningkatkan pengetahuan siswa tentang lingkungan hidup.

Pembelajaran berbasis lingkungan bertujuan untuk membuat siswa berpartisipasi dalam melindungi lingkungan. Tidak memandang lingkungan sebagai sesuatu yang bisa dieksploitasi untuk kepentingan pribadi, tetapi sebagai aset berharga yang layak dilindungi untuk kelangsungan hidup manusia. Oleh karena itu, peting untuk mengembangkan pengetahuan tentang lingkungan, kesadaran lingkungan dan perubahan perilaku terhadap lingkungan. Pendidikan lingkungan dapat membantu siswa 
memikirkan kembali hubungan antara manusia dan lingkungan, memahami lingkungan, menyadari masalah lingkungan dan mempertimbangkan masalah lingkungan yang berkaitan dengan kehidupan (Ramadhan et al, 2019).

Menurut Sukma et al (2020) sebagai individu, manusia memiliki tanggung jawab untuk memecahkan masalah lingkungan. Salah satu solusi yang dapat dilakukan untuk mengatasi permasalahan lingkungan adalah dengan mengetahui semua faktor lingkungan dengan benar agar dapat menjaga lingkungan. Upaya yang paling efektif untuk mencapai tujuan tersebut adalah sistem pendidikan lingkungan yang memadai, dipetakan dan ditujukan untuk memberikan kesadaran, kesadaran dan informasi tentang masalah lingkungan kepada siswa dari semua tingkatan. Peningkatan kesadaran tentang lingkungan dapat diperoleh melalui proses pendidikan. Tujuan pendidikan lingkungan dapat diidentifikasi sebagai transformasi positif dari etika lingkungan individu, pengetahuan lingkungan, kesadaran lingkungan, sikap dan perilaku lingkungan. Pengetahuan, minat, dan sikap masyarakat terhadap lingkungan hidup efektif dalam perilakunya terhadap lingkungan.

Menurut Zulhafizh et al (2013), meningkatnya sikap dan motivasi belajar siswa pada aktivitas belajar sangat diharapkan agar hasil belajar siswa juga meningkat. Lisda dan Sukma (2021) menyatakan hasil belajar sangat erat kaitannya dengan proses pembelajaran. Hasil belajar dapat dilihat dari pengetahuan, keterampilan dan sikap yang dimiliki oleh peserta didik sesuai dengan tujuan pembelajaran. Usaha untuk mengetahui tingkat peran sikap dan motivasi belajar terhadap hasil belajar, khususnya pada pelajaran bahasa Indonesia, perlu dilakukan pengamatan dan analisis terhadap sikap dan motivasi belajar tersebut. Diketahuinya sikap dan motivasi belajar siswa, membantu para guru atau pihak kesekolah dalam merumuskan berbagai strategi yang patut direncanakan dalam mengembang-kan kegiatan belajar mengajar, terutama pada pelajaran bahasa Indonesia berbasis lingkungan. Putri et al (2012) menyatakan pembelajaran ini dilakukan untuk menumbuhkembangkan keterampilan siswa. Terampil dalam menyimak, berbicara, membaca, dan menulis. Hasibuan et al (2021) menyatakan bahwa hasil belajar sangat erat kaitannya dengan proses pembelajaran, hasil belajar dapat dilihat dari pengetahuan, keterampilan dan sikap yang dimiliki oleh peserta didik sesuai dengan tujuan pembelajaran.

Ramadhan et al (2019) mengatakan bahwa dalam pembelajaran bahasa indonesia berbasis lingkungan pendidikan lingkungan penting untuk meningkatkan sikap dan kesadaran peserta didik terhadap lingkungan disekitarnya. Pendidikan lingkungan dapat membuat siswa berpikir secara kritis dan kontekstual. Cara berfikir yang kritis dan kontekstual ini berpengaruh nantinya terhadap pembelajaran bahasa Indonesia, sehingga antara pendidikan 
lingkungan dan pembelajaran bahasa saling berkaitan. Putri dan Syahrul (2019) mengungkapkan bahwa dalam pembelajaran di lingkungan sekolah, pengajaran membaca harus memperoleh perhatian yang serius dari pendidik di Indonesia. Melalui pengajaran, pendidik mampu mengarahkan peserta didik dalam pembelajaran bahasa.

Menurut Sukma (2012) orientasi pembelajaran di sekolah juga perlu mendapat perhatian yang serius. Masih banyak guru bahasa Indonesia yang mengajar dengan pembelajaran yang berorientasi kepada materi pembelajaran. Menurut Sukma et al (2020) pembelajaran di sekolah yang dapat menanamkan karakter positif pada siswa tidak dapat dipaksakan jika hanya terfokus pada pemberian materi yang berkaitan dengan karakter positif. Sukma (2020) menyatakan penanaman karakter penting ditanamkan sejak siswa masih duduk di bangku sekolah dasar. Penanaman karakter dapat dilakukan dalam proses pembelajaran di sekolah. Banyaknya keragaman karakter dan kebiasaan siswa di sekolah berasal dari latar belakang keluarga yang berbeda merupakan pengaruh besar sehingga menimbulkan hal-hal buruk dari karakter anak yang buruk.

Menurut Sukma (2020) pada usia dini, cara belajar yang baik adalah belajar sambil bermain. Upaya guru untuk memberikan materi pembelajaran dengan cara yang menarik namun tetap membuat siswa fokus, sehingga tujuan pembelajaran dapat tercapai. Media pembelajaran yang merupakan wahana untuk memberikan pengalaman belajar. Selain itu, media pembelajaran juga menjadi faktor yang mendukung proses pembelajaran di sekolah dalam menyampaikan informasi. Sebagai alat komunikasi dalam pembelajaran, penting untuk menemukan media pembelajaran yang sesuai dengan siswa.

Menurut Sukma (2012) orientasi pembelajaran sastra di sekolah juga perlu mendapat perhatian yang serius. Masih banyak guru bahasa Indonesia yang mengajar dengan pembelajaran yang berorientasi kepada materi pembelajaran. Menurut Sukma et al (2020) pembelajaran di sekolah yang dapat menanamkan karakter positif pada siswa tidak dapat dipaksakan jika hanya terfokus pada pemberian materi yang berkaitan dengan karakter positif. Pada usia dini ini, cara belajar yang baik adalah belajar sambil bermain. Upaya guru untuk memberikan materi pembelajaran dengan cara yang menarik namun tetap membuat siswa fokus, sehingga tujuan pembelajaran dapat tercapai. Media pembelajaran yang merupakan wahana untuk memberikan pengalaman belajar. Selain itu, media pembelajaran juga menjadi faktor yang mendukung proses pembelajaran di sekolah dalam menyampaikan informasi. Sebagai alat komunikasi dalam pembelajaran, penting untuk menemukan media pembelajaran yang sesuai dengan siswa. 
Menurut Ramadhan et al (2018) model pembelajaran yang inovatif mampu meningkatkan hasil belajar peserta didik. Maka dari itu, pengintegrasian pendidikan lingkungan dalam proses pembelajaran bahasa Indonesia merupakan salah satu cara dalam mewujudkan dan mengembangkan kemampuan siswa sehingga siswa dapat berinovasi dan berkolaborasi dengan lingkungan yang ada disekitar mereka. Ramadhan et al (2019) menyatakan pendidikan lingkungan dapat membantu siswa untuk memikirkan kembali hubungan antara manusia dan lingkungan, mulai memahami lingkungannya, menyadari masalah lingkungan dan mempertimbangkan masalah lingkungan yang berkaitan dengan kehidupan mereka. Itu juga dapat mengubah keseluruhan sistem mentalitas konsumen, pandangan dunia dan pendidikan. Selain itu juga menghasilkan keterampilan perilaku tertentu dalam hubungannya dengan lingkungan, serta mengembangkan optimalisasi dan keselarasan antara manusia dengan alam.

Berdasarkan penjabaran di atas, penulis melakukan penelitian dengan menyebarkan angket mengenai "Kaitan Pembelajaran Bahasa Inodnesia dengan Lingkungan Hidup" kepada mahasiswa Universitas Negeri Padang, Universitas Bairurrahmah, Universitas Andalas, Institut Seni Padang Panjang, Institut Seni Indonesia Solo, Universitas Seni Indonesia Jogja dan Universitas Bung Hatta. Dari jumlah keseluruhan 38 responden yang ikut serta mengisi angket tersebut lebih dominan perempuan 32 responden dan laki-laki 6 responden dengan persentase $84,2 \%$ perempuan, $15,8 \%$ laki-laki. Hasil data dari persentase angket yang telah dilakukan melalui google form tersebut dapat dilihat sebagai berikut.

Pernyataan pertama, "Sangat penting mendidik anak tentang lingkungan sejak dini" $76,3 \%$ menyatakan sangat setuju, 21,1\% menyatakan setuju, $0 \%$ menyatakan kurang setuju, dan $0 \%$ menyatakan tidak setuju. Pernyataan kedua, "Lingkungan sangat penting dalam pembelajaran bahasa Indonesia" 28,9\% menyatakan sangat setuju, 71,1\% menyatakan setuju, 0\% menyatakan kurang setuju, dan 0\% menyatakan tidak setuju. Pernyataan ketiga, "Materi lingkungan dalam pembelajaran bahasa Indonesia dapat diterapkan dalam kehidupan sehari-hari" 44,7\% menyatakan sangat setuju, 52,6\% menyatakan setuju, 0\% menyatakan kurang setuju, dan $0 \%$ menyatakan tidak setuju. Pernyataan keempat, "Pembelajaran berbasis lingkungan bertujuan untuk membuat siswa berpartisipasi dalam melindungi lingkungan" 42,1\% menyatakan sangat setuju, 52,6\% menyatakan setuju, 5,3\% menyatakan kurang setuju, dan $0 \%$ menyatakan tidak setuju. Pernyataan kelima, "Pembelajaran tentang materi lingkungan secara langsung atau tidak langsung dapat membentuk kepribadian mandiri pada siswa" 26,3\% menyatakan sangat setuju, 68,4\% menyatakan setuju, 5,3\% menyatakan kurang setuju, dan $0 \%$ menyatakan tidak setuju. Pernyataan keenam, "Pembelajaran tentang 
lingkungan secara langsung ataupun tidak langsung dapat mengembangkan pola pikir dan bertindak peserta didik" 65,8\% menyatakan setuju, 31,6\% menyatakan sangat setuju, 0\% menyatakan kurang setuju, dan 0\% menyatakan tidak setuju. Pernyataan ketujuh, "Guru memiliki kontribusi penting dalam mengenalkan pengetahuan lingkungan melalui pembelajaran di kelas" 57,9\% menyatakan sangat setuju, 39,5\% menyatakan setuju, 0\% menyatakan kurang setuju, dan 0\% menyatakan tidak setuju. Pernyataan kedelapan, "Upayaupaya pelestarian lingkungan dapat dilakukan melalui teks-teks bacaan dalam pembelajaran bahasa Indonesia" 18,4\% menyatakan sangat setuju, 71,1\% menyatakan setuju, 0\% menyatakan kurang setuju, dan 0\% menyatakan tidak setuju. Pernyataan kesembilan, "Materi lingkungan merupakan topik yang menarik dan beragam untuk dipelajari khususnya dalam pembelajaran bahasa Indonesia" 31,6\% menyatakan sangat setuju, 65,8\% menyatakan setuju, 0\% menyatakan kurang setuju, dan 0\% menyatakan tidak setuju. Pernyataan kesepuluh, "Pembelajaran tentang materi lingkungan secara langsung atau tidak langsung dapat membentuk kepribadian mandiri pada siswa" 63,2\% menyatakan setuju, 26,3\% menyatakan sangat setuju, 10,5\% menyatakan kurang setuju, dan 0\% menyatakan tidak setuju.

Dari hasil penelitian dengan cara menyebarkan angket di atas, dapat disimpulkan bahwa materi lingkungan sangat penting untuk diterapkan dalam pembelajaran bahasa Indonesia. Terbukti saat para responden menganggap peranan dan manfaat lingkungan dalam pembelajaran bahasa Indonesia merupakan suatu hal penting. Masyarakat, khususnya di kalangan mahasiswa dan pelajar, menyadari dan memahami pentingnya peranan lingkungan dalam pembelajaran bahasa Indonesia. Materi lingkungan memudahkan siswa dalam memamahami materi bahasa Indonesia dengan baik, menambah wawasan siswa, serta dapat membangun kecerdasan ekologis siswa. Materi lingkungan merupakan materi yang sangat erat kaitannya dengan kehidupan sehari-hari. Oleh karena itu, dengan materi lingkungan guru bisa dengan mudah mencari contoh relevan yang membuat siswa lebih paham akan materi yang diberikan, sehingga dapat membantu guru dalam mengimplikasikan materi bahasa Indonesia di sekolah. Hal ini sesuai dengan pendapat Ramadhan et al (2019), dengan mengintegrasikan pendidikan lingkungan ke dalam kelas, guru dapat meningkatkan minat siswa terhadap permasalahan kontemporer yang mungkin langsung mempengaruhi masa depan mereka. 


\section{DAFTAR PUSTAKA}

Guci, Ira, R. Syahrul, and Nursaid Nursaid. (2018). Korelasi Penguasaan Kosa Kata Bidang Lingkungan Hidup dengan Menulis Karangan Argumentasi Tentang Lingkungan Hidup. Jurnal Pendidikan Bahasa dan Sastra Indonesia, Volume 1, Nomor 2, p 169-174.

Hasibuan, Lisda Selviana, and Elfia Sukma. (2021). Peningkatan Hasil Belajar Peserta Didik Pada Pembelajaran Tematik Terpadu Menggunakan Model Kooperatif Tipe Numbered Head Together (NHT) di Kelas IV SD. Jurnal Pendidikan Tambusai, Vol 5, No 2, p 4504-4510.

Putri, Diana dan Syahrul R. (2019). Korelasi Keterampilan Membaca Pemahaman dan Keterampilan Menulis Teks Laporan Hasil Observasi Siswa Kelas VII SMP Negeri 4 Pariaman. Jurnal Pendidikan Bahasa dan Sastra Indonesia, 8(1), seri A 62-69.

Ramadhan, S., Elfia Sukma, dan Vivi Indriyani. (2019). Environmental Education and Disaster Mitigation Through Language Learning. IOP Conference Series: Earth and Environmental Science, 314, p. 1-9.

Ramadhan, S., Yasnur Asri, dan Vivi Indriyani . (2018). Learning Module Design Writing Argumentative Text Based Problem-Based Learning. Advances in Social Science, Education and Humanities Research, Vol 263: 194-200.

Selviana, Lisda and Elfia Sukma (2021). Peningkatan Hasil Belajar Peserta Didik Pada Pembelajaran Tematik Terpadu Menggunakan Model Kooperatif Tipe Numbered Head Together (NHT) di Kelas IV SD. Jurnal Pendidikan Tambusai, Volume. 5, No 2, p 4505.

Sukma E, dan VP Azrianti. (2020). Instilling Positive Characters in Students Using Folker in the Macromedia Application. Advances in Social Science, Education and Humanities Research, Volume 485, p 370-383.

Sukma, Elfia, Syahrul Ramadhan, and V. Indriyani. (2020). Integration of environmental education in elementary schools. Journal of Physics: Conference Series. Vol. 1481. No. 1. IOP Publishing.

Sukma, Elfia. (2012). Pembelajaran Sastra yang Integratif Berbasis Kompetensi. International Conference on Languages and Arts. Halaman 432-436. 
Zulhafizh, Atmazaki, dan Syahrul Ramadhan. (2013). Kontribusi Sikap dan Motivasi Belajar Siswa terhadap Hasil Belajar Bahasa Indonesia. Jurnal Bahasa, Sastra dan Pembelajaran, Volume 1, Nomor 2, Halaman 13-28. 